\section{Fakta og fiktion i mediernes historiebilleder}

Af Werner Svendsen

I indbydelsen til dette seminar stilles bl.a. spørgsmålet: Har Matador betydet mere for danskernes historieopfattelse end uddannelsessystemet? Det er et interessant spørgsmål, som jeg mener at kunne besvare bekræftende. Matador blev sendt i årene 1978-81 og var resultatet af et vellykket joint venture mellem en journalist, der nød at kunne bruge fiktions-formen, og en instruktør, som nød at tilføre fiktionen så mange virkelighedsdetaljer som muligt. Man opnåede på den måde i ét og samme værk at forenkle og perfektionere det historiske virkelighedsbillede. Intet dokumentarprogram kunne have leveret et på samme tid så forenklet og overbevisende historisk virkelighedsbillede, befolket af arketyper, der lignede levende mennesker, og hvis liv og skæbne man kunne leve sig ind i og identificere sig med.

Dette med identifikationsfaktoren i tv var i øvrigt noget væsentligt $\mathrm{i}$ mediets guldalder frem til sidst $\mathrm{i}$ 1980 'erne. I BBC oplevede man i 1960'erne, at hovedpersonerne i de populæreste tv-serier blev så levende for mange seere, at de sendte breve i tusindtal direkte til dem, så BBC forsøgsvis oprettede et kontor, hvor forfattere og journalister sad og skrev svarbreve fra hovedpersonerne til seerne. Et fænomen, man kunne kalde „livet på anden hånd“.

Men altså - Matador er ikke fakta og ikke ren fiktion, men et blandingsprodukt, en journalistisk fiktionsserie. Dengang Danmarks Radio var et monopol - og det vil sige frem til sidst i 1980 'erne - var der ellers vandtætte skodder mellem fiktion og fakta. Fiktion tog de sig af i Teater-og Underholdningsafdelingen; fakta, det rent dokumentariske, tog vi os af på TV-Avisen og i Kulturafdelingen, som jeg var programchef for i 22 år, fra 1967 til 1989. Når vi lavede historiske programmer, skete det i form af ekskursioner ud i det danske land, hvor Palle Lauring og Erik Kjersgaard dukkede op over bakkekammen ved Dybbøl, på Hammershus eller kom ud ad en dør på Kastellet og fortalte løs som nationens historielærere. Andre programmer havde karakter af lysbilledforedrag med malerier, tegninger og dokumenter fra tiden og ellers en fortæller i billedet. Vi løste også store og krævende dokumentaropgaver - f.eks. serien Danmark under besattelsen, hvor unge besættelsestidshistorikere som Hans Kirchhoff, Henrik S. Nissen, Henning Poulsen, Finn Løkkegaard og flere andre udarbejdede de på fakta velfunderede skildringer af centrale kapitler af Danmarks historie, billeddækket med autentiske filmstumper eller fastbilleder. Samtidig købte vi jo også en del udenlandsk producerede dokumentarserier, f.eks. om Nazi-Tyskland, om 2. verdenskrig eller 1. verdenskrig, kapitler af mellemkrigstidens historie osv.

Behovet for mere programstof voksede hastigt i løbet af 1960'erne og 
1970 'erne, og antallet af produktioner steg kraftigt. Det hændte ikke så sjældent i de år - især i udlandet - at man pludselig stod over for en central begivenhed, der aldrig var blevet filmet eller fotograferet, og som skulle omtales. Så kom man i tanke om en spillefilm, der havde rekonstrueret netop den pågældende begivenhed både præcist, velilluderende og spændende. Det blev mere end fristende for mange producenter at sakse en sådan stump spillefilm og indsætte den blandt dokumentarklippene. Middelalderhistorikeren Niels Skyum-Nielsen gjorde det fra sidst i 1960'erne og frem til sin død i 1982 til en af sine livsopgaver at håndhæve kravet om autenticitet i billedmateriale og lydoptagelser i medierne, ikke mindst i tv-programmer, der gav sig ud for at være dokumentariske. Han gjorde en fremragende indsats, efterhånden med en gruppe yngre historiker-kolleger omkring sig, offentliggjorde undersøgelser og materialesamlinger og var i en permanent dialog med os i tv-mediet. Udbuddet var dengang til at overskue programmængden var ikke enorm på én tv-kanal. Niels Skyum-Nielsen var en beundringsværdig pioner, der kæmpede den ædle kamp. I dag er det sværere endnu er overvågningen mulig $\mathrm{i}$ et vist omfang i bøgernes verden, som vi i de seneste uger har set aktuelle eksempler på. På tv-området er det i dag på det nærmeste umuligt at kontrollere det dokumentariske stof, og det er ikke alene programmængden, der er forklaringen på det.

Ligesom det var fristende for dokumentarfilmfolkene at ty til spille- film, når de skulle bruge visuelle skildringer af samtidshistoriske begivenheder, der af mere eller mindre forklarlige årsager aldrig var blevet filmet, dengang de fandt sted, blev mange spillefilmfolk i 1970'erne og 1980'erne fascineret af den selvsamme opgave: at forsøge så præcist ned i detaljerne som muligt at rekonstruere centrale begivenheder, som ellers kun lod sig skildre med helt tilfældige filmstumper eller fotografier faktion døbte man genren, dvs. dokumentariske fiktionsfilm med skuespillere.

Faktion var som skabt til tvmediet. Havde man ikke vidst det før, fandt man ud af det i 1970'ernes USA, da de store reklamefinansierede tvselskaber udkæmpede rene gladiatorkampe om deres massepublikums gunst og dermed om reklamekronerne. I 1973 havde den amerikanske forfatter Alex Haley udsendt romanen Roots, Rødder, en sort families saga, hvor han på grundlag af 12 års kildestudier fortalte sin families historie på mødrenes side tilbage til Afrika. Over denne roman skabte CBS i 1977 en tv-serie, der vakte en uhyre interesse for kultur- og slægtshistorie i USA og i væsentlig grad bidrog til en ændret holdning til de sorte i USA. Succesen var enorm, seertallene toppede, og de konkurrerende selskaber så sig om efter noget tilsvarende. Hos NBC traf man et dristigt valg, da man besluttede sig for at producere den i øvrigt næste ukendte forfatter Gerald Greens roman Holocaust. Bogen - der fortæller om to slægters historie i Tyskland i årene 1935-1945, den jødiske familie Weiss og den nazistiske familie 
Dorf - hører kunstnerisk set hjemme i letvægtsklassen. Men alle sejl blev sat til i tv-produktionen, der omfattede fire afsnit af hver et par timers varighed. Især researchen var omhyggelig. Præcise detaljer fra øjenvidneskildringer og beretninger fra mange overlevende fra dødslejrene indgik i opbygningen af billedsiden. Replikkerne skurrede ofte fælt, men skuespillerne var gode, og et uhyrligt og ufatteligt mareridt blev pludselig gjort begribeligt, fordi man oplevede det ved at følge konkrete mennesker, hvis liv og skæbne alle kunne identificere sig med.

Holocaust blev produceret $\mathrm{i}$

1978, samme år som Matador, og var alt $\mathrm{i}$ alt et topprofessionelt arbejde, dygtigt filmet og spillet. De falske, men rystende virkelighedsilluderende billeder greb den almindelige seer dybt om hjertet. Serien blev en gigantisk succes i USA, en af de største i landets tvhistorie, og man lagde an til international eksport. Først til England, hvor mange gode og kloge hoveder samledes i massiv protest mod, hvad de opfattede som kynisk følelsesporno. Den senere berømte engelske tv-dramatiker Dennis Potter søgte i en stor artikel i Sunday Times at åbne publikums øjne for bedrageriet. „Grænsen er overskredet, når man med soap-opera-virkemidler vil skildre det virkelige liv og den totale terror“, skrev han og fortsatte: „De snesevis af nøgne statister, der stod skælvende ved de allerede åbne grave, var instrueret med omhu, for at de ikke skulle fremvise deres kønsorganer for kameraerne. Den bedste sendetids regler for god opførsel er altså - såre rosværdigt
- stærke nok til at overvinde nazistiske befalinger". Men kritikken og protesterne hjalp ikke, kunne ikke hindre seersuccesen.

I flere andre europæiske lande var man nærmest enige med Dennis Potter, bl.a. i Frankrig og Danmark, hvor Teaterafdelingen afviste serien som tv-dramatik af for ringe kunstnerisk kvalitet. I Tyskland tøvede man lidt emnet var her særlig ømtåleligt - men endte med at beslutte sig for at sende serien og lade hvert af de fire afsnit blive efterfulgt af en debat i studiet. Udsendelserne blev bragt i januar 1979. I en af disse debatudsendelser blev et brev læst op fra en tidligere SS-officer, som bad diskussionsdeltagerne bekræfte, at ikke alle SS-folk havde gjort tjeneste i koncentrationslejre eller på anden måde deltaget i grusomhederne. Hans hustru var nemlig efter at have set de to første afsnit af historien om familierne Weiss og Dorf fortvivlet trængt ind på ham for at få ham til at fortælle om sine handlinger under krigen. Nedslaget hos den vesttyske befolkning var helt uventet chokerende voldsomt. Tyve millioner vesttyskere sad klinet til skærmen de fire aftener, og tusinder af følelsesladede scener udspilledes rundt om i hjemmene. Mange unge blev her for første gang klar over deres forældres skyldkomplekser, de fattede en virkelighed, de ikke havde kendt til før, og udspurgte inkvisitorisk deres forældre. Det blev sandhedens time i mange hjem. Mange unge var forfærdede, andre unge blev tilsyneladende grebet af en næsten pervers nostalgi efter den tid, da deres forældre havde været unge, og hvor der 
havde været handlekraft, idealer, noget at tro på, et fællesskab. Mange drømte, sagde de, om blodrusen fra dengang. I de følgende måneder af 1979 gik en bølge af ungdomsoptøjer, antisemitiske og pro-nazistiske demonstrationer over Vesttyskland, en uhyggelig variant af det traditionelle generationsopgør. I regering og forbundsdag førtes panikagtige debatter om baggrunden for dette pludselige, krigslignende klima i forbundsrepublikken. Vesttysk tv havde i årene op til 1979 sendt snesevis af rystende dokumentarfilm om Det Tredje Riges forbrydelser. Alligevel virkede det, som om hovedparten af befolkningen, især ungdommen, oplevede denne amerikanske tv-beretning som en rystende nyhed.

Det øvrige Europa fulgte forbløffet tumulterne i Vesttyskland. I Frankrig havde alle tre tv-kanaler af kvalitetsgrunde kasseret Holocaust-serien, men så bragte ugemagasinet L'Express et interview med en herre ved navn Louis Pellepois. Han havde under krigen været kommissær for jødiske anliggender og den direkte ansvarlige for, at Frankrigs jøder var blevet sendt til de tyske koncentrationslejre. $\mathrm{Nu}$ hævdede han $\mathrm{i}$ interviewet, at hele Holocaust-mareridtet, alt dette med seks millioner myrdede jøder, var løgn og digt. „Det var kun lusene, man gassede $\mathrm{i}$ Auschwitz", udtalte han, og den efterfølgende debat viste, at han langt fra stod alene med sin opfattelse. Faktisk fik han en overrumplende stor opbakning, og Antenne 2 skyndte sig nu at købe serien og programsatte den i februar 1979.

I Danmark havde serien som sagt allerede været til gennemsyn hos
Teaterafdelingen, der havde kasseret den af kvalitetsgrunde. Men seriens skæbne i Tyskland og Frankrig og andre steder gjorde også en genovervejelse her hos os naturlig. Vi endte med at antage serien i Kulturafdelingen, fordi den var et bemærkelsesværdigt mediefænomen og sendte den over fire aftener den første uge af marts 1979 - hver aften efterfulgt af korte dokumentarfilm og en direkte debat i studiet mellem fire (hver aften forskellige) deltagere, bl.a. dokumentarfilminstruktøren Erwin Leiser, historikeren Karsten Fledelius og chefredaktør Herbert Pundik, med mig som ordstyrer.

Claus Bryld og Anette Warring skriver i deres bog Besattelsestiden som kollektiv erindring fra 1998, at serien blev købt til dansk tv bl.a. efter krav „fra jødiske kredse“. Den påstand vil ikke kunne dokumenteres. Det var mig, der traf beslutningen, og jeg kender intet til en sådan pression. Her som flere andre steder blev serien købt som det mediefænomen, den var. I løbet af 1979 blev serien vist i 31 lande.

Sidst i 1970 'erne, da Matador og Holocaust gik over skærmene, havde journalisten Paul Hammerich, som også forfattede adskillige afsnit af Matador, skrevet den nyere tids Danmarkshistorie om årene 1945-1972. Han kaldte den ikke en Danmarkshistorie, men en Danmarks-krønike - og krønike betyder som bekendt dels en kronologisk fremstilling af historiske begivenheder, dels en fortælling med eventyrligt indhold eller, om man vil, en historie der er fuld af løgn. Det var den nu ikke; skildringen var ganske vist både personlig og 
subjektiv, men researchen var i orden. Det stof var lige noget for os i Kulturafdelingen. Vi var med efterkrigstiden så langt oppe i vor egen tid, at vi regnede med at have rigeligt autentisk billedmateriale til at billeddække Hammerichs - i forhold til bogversionen stærkt koncentrerede - tekst. Men det havde vi ikke. Overraskende nøglebegivenheder var der hverken film eller fotografier fra. Nogle af problemerne blev løst, da vi efterlyste amatøroptagelser og fik tilsendt bjerge af dem, men ofte måtte Paul Hammerich sidde på skærmen og fortælle uden billeder. Det var ikke noget, der huede os. Anfægtelser med hensyn til brug af spillefilm havde vi jo ikke her, så dem brugte vi løs af. Tidens spillefilm var en del af historien - var i sig selv dokumentarisk materiale.

Men det lader sig ikke nægte, at det blev gradvist mere og mere frustrerende at være sat til strikt at forvalte kendsgerninger, fakta, mens de ovre i Teaterafdelingen kunne lade fantasien boble og under dække af etiketten „fiktion" skabe overbevisende virkelighedsbilleder, f.eks. Leif Panduros nærbilleder af familien Danmark, mere dybdeborende end Matador's, men på samme måde repræsentative. Også Leif Panduro hørte til i kredsen omkring Lise Nørgaard og Paul Hammerich. Når bare det hed fiktion, var der ingen restriktioner.

Vi levede dengang i monopoltider med et dynamisk, politisk valgt Radioråd, et magtfuldt mini-folketing, som på åbne programudvalgsmøder hver 14. dag diskuterede med sultne reportere i presselogen. Radiorådet var i 1970'erne og 1980'erne Danmarks mest eftertragtede talerstol, og alle tidens toppolitikere havde på skift haft deres gang i Radiorådet. Radiorådet havde en klar mening om, at Teaterafdelingen og Underholdningsafdelingen måtte lave fiktion, mens Kulturafdelingen og TVAvisen skulle fremlægge fakta. Men som bekendt var der mange eksempler på, at det kunne diskuteres, hvad der var kendsgerninger. Alt afhang af, hvilke øjne der så. Som oftest reddede vi os igennem de hede debatter om kontroversielle emner ved at hale eksperter ind og påberåbe os deres dokumentation.

Men under f.eks. den heftige debat om atomkraft i Danmark kom både tilhængere og modstandere slæbende med hver deres eksperter. Den sagkyndige fra Risø var for og beroligede, mens professoren i atomfysik ved Københavns Universitet nærmest var imod og udtrykte stor bekymring. Det blev en religionskrig mellem troende og vantro. Kendsgerninger var pludselig blevet noget relativt. I denne situation drømte vi mere end nogensinde i Kulturafdelingen om at dække os bag fiktionens beskyttende dække og havde på en måde allerede taget første skridt, da vi i 1983-84 præsenterede tv-serien Gamle Danmark, bygget over Paul Hammerichs

\section{Danmarkskrønike.}

I 1984 fik vi en henvendelse fra svensk tv, som foreslog os at gå med i en co-produktion om en dramadokumentarisk tv-serie med et emne fra besættelsesårene, nemlig historien om Jane Horney.

Gåden Jane Horney havde gennem flere år optaget sindene i 
Sverige. Man mente at have dokumentation for, at der var foregået et justitsmord, at Jane Horney havde været en på mange måder letsindig ung dame, som med samme overfladiske charme havde plejet omgang med tyske officerer og danske modstandsfolk, men at de alvorlige beskyldninger om stikkervirksomhed, som førte til, at den danske modstandsbevægelse likviderede hende i januar 1945, var grundløse. Den synopsis, vi fik forelagt, virkede spændende, et kontroversielt stykke besættelseshistorie, men ikke mere kontroversielt end at vi stilede mod at udsende seriens seks dele i maj 1985 med premiere den 3. maj i prime time. Hvis enten svenskerne eller vi havde valgt at producere et almindeligt dokumentarprogram, der byggede på dokumenterede kendsgerninger, ville resultatet på det tidspunkt være blevet pauvert, for det skortede helt klart på uigendrivelig dokumentation. Fremstillingen måtte i mangt og meget bygge på indicier, uklare eller modstridende rapporter og tvivlsomme øjenvidneberetninger. Den svenske filmproducent og instruktør Stellan Olsson, der var ansvarlig for manuskriptet og leder af researchholdet bag serien, blev bestyrket i troen på en god historie, da bl.a. det danske justitsministerium efter henstilling fra Rigsarkivet kategorisk nægtede de svenske researchere adgang til det eksisterende kildemateriale. $\mathrm{Nu}$, set $\mathrm{i}$ bakspejlet, var resultatet af de mange og store anstrengelser ikke imponerende. Modstandsmiljøerne var skildret uden inside-viden, skuespillerpræstationerne var generelt på det jævne, og selve historien manglede sammenhæng. For så vidt var det færdige produkt ikke nogen god sag at forsvare professionelt. Men Jane Horney-serien blev på en anden måde end Holocaust-serien anskuelsesundervisning i problemerne omkring formidling af samtidshistorie i et monopolmedie. Som Claus Bryld og Anette Warring formulerer det i deres bog: „Fejden om serien blev den hidtil største offentlige strid i Danmark om en fremstilling af et stykke besættelseshistorie, ja, formentlig om et stykke historie i det hele taget". Allerede omkring den planlagte premiere i maj var velorganiserede protester mod serien, hvis indhold ingen udenforstående endnu kendte noget til, begyndt at løbe ind; enkelte i form af nye oplysninger, som vi fandt det påkrævet straks at få svenskerne til at efterforske nærmere. Udsendelsestidspunktet blev flyttet et lille halvt år, og svenskerne reviderede manuskriptet på adskillige punkter. Gradvist dæmrede det for os i Kulturafdelingen, at vi var i færd med at gøre noget formasteligt - at vi var i gang med at krænke uskrevne, men særdeles ukrænkelige love for, hvad der måtte fortælles om den danske modstandsbevægelse og dens handlinger under besættelsen. Alle de mange tv-programmer, vi op til 1985 havde produceret og sendt om besættelsestiden og modstandsbevægelsen, havde bygget på faghistorikeres arbejde og havde kun yderst sjældent indeholdt kritik af modstandsbevægelsen. Nu kom kritikken så at sige udefra, fordi svensk tv med os som co-producenter havde den åbenlyse intention at rehabilitere en svensk statsborger ved at påvise, at den danske modstandsbevæ- 
gelses grundlag for at likvidere hende ikke havde været holdbart. I månederne fra maj til oktober 1985 fremkaldte alene rygterne om indholdet af den endnu ikke udsendte serie flere pressionsforsøg og trusler mod tv-ledelsen i almindelighed og mig i særdeleshed end hidtil oplevet i Danmarks Radios historie. Alene fra september til december 1985 bragte landets ni største dagblade mere end 300 egentlige artikler, ofte på forsiden. Og da serien fra den 21 . oktober 1985 vistes over seks mandage, voksede uvejret til orkanstyrke, som holdt sig næsten frem til jul. De trusler, jeg selv oplevede, var ofte særdeles konkrete. En anonym telefonstemme meddelte mig en sen aften tydeligvis med en præcis viden om indretningen af vores hus i Hellerup hvordan først mine børn, så min kone og jeg ville blive likvideret. Der var dage, hvor jeg havde politieskorte, når jeg kørte til TV-Byen. I sig selv blev det opfattet som uhørt, næsten som landsforræderi, at sætte spørgsmålstegn ved en likvidering, foretaget af den danske modstandsbevægelse. Endnu værre var det, at serien mente at have belæg for at påstå, at Jane Horney blev likvideret, fordi hun sad inde med en farlig viden om et samarbejde - faktiske aftaler mellem dele af den danske modstandsbevægelse og tyske officerer i 1944-45. Her sigtedes til borgerlige modstandsfolk, ofte militærpersoner, som på den måde skulle have spillet dobbeltspil med den civile - især den ikke-borgerlige - del af modstandsbevægelsen. Den slags spændinger var velkendte inden for alle eúropæiske modstandsbevægelser, og det var vel ikke helt usandsynligt, om noget lignende også var forekommet i Danmark. Researchholdet havde fundet materiale fra efterretningstjenesten i Stockholm og det engelske SOE, der kunne tolkes i den retning. I en ren dokumentarudsendelse havde man næppe kunnet klassificere dette materiale som overbevisende, men i en dramadokumentarisk beretning var det acceptabelt at forestille sig sammenhænge, der var klare indicier for.

Som tv-produktion blev Jane Horney-serien som nævnt ikke vellykket, men den faktuelle historie, den fortæller, er aldrig blevet overbevisende dementeret. Året efter (i 1986) udsendte Erik Nørgaard en 700 sider stor dokumentarisk redegørelse for Jane Horneys liv og død med en klar konklusion: Likvideringen var en tragisk fejl.

Efterfølgende spurgte vi os selv i tv-ledelsen, om reaktionerne på serien ville have været andre og mindre følelsesladede, hvis vi havde holdt os strikt til kendsgerningerne, og svaret måtte blive, at så havde denne serie ikke kunne laves. Der findes historie og historier, som kun kan skildres i fiktions-form. Det fastslog bl.a. Erik Kjersgaard, der om nogen havde formidlet historie via tv-skærmen. Han skrev engang:

„Det er nok en opgave, der ligger bedre for en skønlitterær forfatter end for en historiker: at skildre et sådant samfund, hvor faderen kunne være medlem af DNSAP og sønnen af Dansk Terrænsportsforening - en næsten sikker indslusning til modstandsbevægelsen, hvor skibsværftsarbejdere reparerede tyske minestrygere om dagen og øde- 
lagde dem om natten, hvor folk frit kunne spise frokost med Dr. Best og drikke aftenkaffe med repræsentanter for Frit Danmark. Og hvor de fleste stadig gik til barberen, stod i kø hos slagteren, morede sig over Christian Arhoff i biografen, bekymrede sig om børnenes underlødige læsevaner og de unges slappe moral, ikke kunne få husholdningspengene til at slå til og blev opskræmt af forlydender om tiltagende fare for kønssygdomme, difteritis og tuberkulose. Kompleksiteten i et sådant samfund unddrager sig historikerens grove værktøj; han kan registrere fænomenerne ét for ét, men ikke deres samspil i det følsomme instrument, der udgør menneskers bevidsthed“.

Langt fra alle historikere er enige med ham. Claus Bryld og Anette Warring gør sig i deres bog om Besattelsestiden som kollektiv erindring til talsmænd for en opblødning af grænserne mellem fakta og fiktion. De kalder Kjersgaards holdning for „purisme“ og fortsætter: „Tænker historikeren grovere end forfatteren? Vi tror, at historikerne må begynde at frigøre sig for dette paradoks og i højere grad reflektere både over deres metode - om den er for deskriptiv og for lidt empatisk - og over deres fremstillingsform".

Uenigheden kommer til udtryk hos historikerne også i dag. Så sent som i Berlingske Tidende den 9. november 1999 udtalte historikeren Sidsel Eriksen: „Hvis historiefortællingen trækkes for meget over mod fiktionen, er det farligt. Så bliver historie til klicheer og myter". Men i samme nummer af avisen lægger et par andre historikere, Adam Holm og Peter Scharff Smith, sig nærmest på linje med Bryld og Warring: „Det er frustrerende, at nuancer har svært ved at gøre sig i medierne, at medierne appellerer til det journalistiske krav om enkle konflikter. Men det nytter ikke, at vi sidder og tørrer øjne over, at vore budskaber bliver forvansket. Det er vigtigt at blande sig, hvis man har en viden, der beriger samfundsdebatten og vores selvforståelse“" Og de taler om at operere med en blanding af følelser, personlige erfaringer, historie og politik. „Det sætter nutidens akademiske arbejde i perspektiv".

Alle erfaringer siger mig, at både fiktions-formen og faktionsformen som formidlingsgenre er mere effektive end den tilstræbte objektive fakta-form. Også i den vil der i øvrigt altid være foretaget en lang række skjulte, subjektive valg. Men da faktaformen taler mindre til følelserne, skaber den nok også færre myter. Til gengæld også mindre liv, mindre dialog og debat. Den objektive sandhed får man ikke i nogen af genrerne.

$\mathrm{Nu}$ skulle mit oplæg jo handle om mediernes historiebilleder, altså ikke kun tv's. Lad mig derfor omtale et enkelt aktuelt eksempel fra bøgernes verden, hvor jeg har arbejdet som forlægger den sidste halve snes år. På Forum udgiver vi den berømte, italienske forfatter Primo Levi, en fremragende kemiker, der under 2 . verdenskrig gik ind i modstandsbevægelsen, blev fanget og i februar 1944 deporteret til Auschwitz, hvor han kun overlevede frem til befrielsen, fordi man havde brug for hans kvalifikationer som kemiker. 
Bagefter var Primo Levi besat af tanken om, at menneskeheden aldrig nogen sinde måtte glemme, at disse lejre havde eksisteret. Han udsendte en række bøger - nogle øjenvidneskildringer, andre præsenteret som romaner eller noveller - der alle handler om og bygger på hans afskyelige oplevelser i lejren. Eftervirkningerne af Auschwitz førte til hans selvmord i 1987.

I 1995 udkom i Tyskland en lille bog på det ansete Suhrkamp Verlag. Den hed Brückstücke. Aus einer kindheit 1939-1945. Forfatteren Binjamin Wilkomirski boede i Schweiz og var midt i halvtredserne. Han var klarinettist og byggede musikinstrumenter. Fraskilt med to børn. Tilsyneladende en almindelig borger i det fredelige Schweiz. Men han sagde, han ikke vidste, hvem han var. Officielt er han født i Schweiz i 1941 i byen Biel og vokset op hos plejeforældre. Men under hele sin opvækst har drengen og senere den voksne mand været plaget af mareridtsagtige erindringer om en barndom i Polen, måske Letland. Han husker navne som Majdaneck, Krakow og Riga og ved med sikkerhed, at hans virkelige navn er Binjamin Wilkomirski. Han går i behandling hos en psykoanalytiker, som en dag efter lang tids behandling beder ham nedskrive, hvad han husker. Det gør han, og det gør et så stærkt indtryk på psykoanalytikeren, at han foreslår, at disse brudstykker af erindring udgives.

Det bliver de - som sagt - hos Suhrkamp Verlag og senere købes de af andre lande, bl.a. Danmark, hvor vi udgav bogen på Forum. Niels Barfoed skrev i Politiken bl.a.:
„Bogen er noget meget ejendommeligt, fordi dens erindring på én gang har den præcision, som er karakteristisk for meget tidlige oplevelser, dels er omgivet af et drømmeagtigt, næsten selvlysende skær, fordi det er en førsproglig bevidsthed, der har forvaltet dem. Han og de andre børn, der ikke sygner hen og dør eller bliver straffet til døde, lever - eller hvad det nu hedder sig ind $\mathrm{i}$ en verden, hvor der ikke findes mødre mere, og hvor der aldrig vil være mødre. Binjamin og hans kammerat Jankl 'levede begge blandt levende, men uden rigtigt at høre til blandt dem døde, der egentlig var på en illegal ferie og kun var forblevet i live ved en fejltagelse' ,.

„Jeg kan faktisk ikke overkomme“ - fortsætter Niels Barfoed - „at give et indtryk af, med hvilke midler disciplinen blev opretholdt i børnebarakken, hvilket menneskeligt forfald der var tale om, eller i hvilken forstand Binjamin så sine jævnaldrende dø omkring sig. Det hele havde en sådan traumatiserende karakter, at han siden aldrig kom ud af lejren. Da han første gang som 8-årig så en skilift, flygtede han over hals og hoved. Det var i Schweiz, og de forældreløse børn var på udflugt. Han så børnene blive spændt fast, løftet op og glidende og i en frygtelig stilhed forsvinde over en bjergkam. Da vidste han, de var på vej til tilintetgørelsen. Lejren var hele verden. Det gode liv er kun en fælde. I virkeligheden blev han aldrig befriet".

Thomas Thurah skrev i Weekendavisen under overskriften „Knusende bog“, at „forfatterens fragmenterede og 
drømmeagtige erindringer fra en barndom tilbragt i tysk koncentrationslejr røber en rystende sandhed, ikke kun om fornedrelsen og myrderierne, men også om den verden, der lå uden for lejrene og på den anden side af krigsafslutningen". Og Thomas Thurah fortsætter: „Der er afgørende forskelle mellem Primo Levis bøger, Imre Kertész' roman og Binjamin Wilkomirskis erindringer (genreforskellen er en af de mindste), men de har to afgørende ting til fælles: Den ene er, at deres forfattere ikke vil i terapi hos deres læsere; måske har nedskrivningen tjent det formål, men det vedrører i givet fald netop nedskrivningen, ikke læsningen. Forfatteren skal ikke trøstes, det har man venner til, ikke læsere. Det andet fællestræk er alt det, der ikke er med, det der ikke står der. Levis første bog kom et par år efter krigen, hans sidste godt og vel fyrre år efter, Kertész' roman tredive år efter og Wilkomirskis bog halvtreds år efter. De har alle skullet gøre sig fri af de forestillinger og myter, der eksisterede om lejrene".

På klapteksten til den danske udgave - Brudstykker. Af en barndom 1939-1948 - der udkom i efteråret 1996, havde jeg bl.a. skrevet: „Har disse børnemord virkelig fundet sted, eller hører de hjemme i en fantasi, hvor mennesker forvandles til trolde og udyr? I bogens virkelighed er de autentiske“.

Denne sidste sætning bliver pludselig væsentlig, da det et par år senere, i 1998, dokumenteres af en schweizisk journalist, at Wilkomirski aldrig har været i en dødslejr, at han er født i Schweiz uden for ægteskabet og siden bortadopteret til et schweizisk ægtepar. Det var korrekt, at han i årevis havde været plaget af sine mareridt fra en dødslejr, og at deres baggrund var uforklarlig. Han havde aldrig været uden for Schweiz som barn.

For en måneds tid siden, dvs. i oktober 1999 i tilknytning til årets bogmesse i Frankfurt, trak Suhrkamp Verlag Wilkomirskis bog tilbage med den begrundelse, at den havde vist sig at være fiktion. Hans danske forlag har ikke det problem, eftersom den danske udgave har været på nedsættelse og i dag er udsolgt. Men tilbage står efter min mening et centralt spørgsmål: Ændrer de nye oplysninger ved tekstens kvalitet? Står ordene der ikke stadig med den kraft, der gør teksten til næsten ubærlig læsning? Hvis vi havde skrevet fiktion på titelbladet, ville det så have svækket bogens tekst? Primo Levi kalder flere af sine erindringsværker for fiktion. De berømte skildringer af slagmarkernes helvede i Remarques Intet nyt fra Vestfronten rystede en hel verden, men de byggede ikke på selvoplevelser.

Remarque var aldrig personligt i frontlinjen. Men der stod roman på titelbladet, så ingen kunne forvente selvoplevelser.

Er fiktion mere ansvarsfri, mindre autoriseret end såkaldt nonfiction? Eller har man lov til at hævde, at Binjamin Wilkomirski har beskrevet sine mareridt så præcist og rystende, at de „i bogens virkelighed er autentiske"? 